\title{
Pattern of Lyme arthritis in Europe: report of 14 cases
}

J P HUAUX, ${ }^{1}$ G BIGAIGNON, ${ }^{2}$ S STADTSBAEDER ${ }^{2}$ P F ZANGERLÉ,$^{3}$ AN $\frac{\bar{c}}{\overline{\bar{c}}}$ C NAGANT DE DEUXCHAISNES ${ }^{1}$

From the Departments of ${ }^{I}$ Rheumatology and ${ }^{2}$ Microbiology, St-Luc University Hospital, Louvain Universif in Brussels, Avenue Hippocrate 10, B-1200 Brussels, and the ${ }^{3}$ Department of Rheumatology, Centre Hospitalier de Ste-Ode, B-6970 Tenneville-Baconfoy, Belgium

SUMMARY Fourteen cases of Lyme arthritis are reported. The most frequent picture was that of oligoarthritis appearing in that part of the leg where the cutaneous or neurological complications or both, of Lyme disease had developed before the arthritis. In most cases recovery followed $\vec{a}$ single 10 day course of intravenous (IV) penicillin therapy. Arthritis was the presenting feature of Lyme disease in three cases.

Definite arthritis was reported frequently in Lyme disease in the USA in the late 'seventies ${ }^{1}$ and in Europe,$^{2-11}$ where, however, it seemed to be less severe and less frequent. ${ }^{9-12}$ In the last two years we have seen 14 cases of Lyme arthritis. We report them here and discuss their prevalence, clinical pattern, and natural evolution.

\section{Case reports}

Fourteen patients (nine female, five male), mean age 40 years (range 12-62), were seen in 1986 and in the first months of $1987 .{ }^{1}$ The diagnosis of Lyme disease was established on clinical grounds and confirmed by the presence of serum antibodies against Borrelia burgdorferi detected by means of enzyme linked immunosorbent assay (ELISA) (IgG, IgM). Each positive sample was confirmed using an indirect immunofluorescent antibody test (IFAT). A dilution of $1 / 128$ was considered positive. The borrelia strain was supplied by Professor Ackermann (Cologne, West Germany).

All our patients suffered from true inflammatory arthritis with synovial swelling. Four had monarthritis (knee $(n=3)$; wrist $(n=1))$. Eight had oligoarthritis (less than four joints affected), involving mainly the knee, the ankle, and a few metatarsophalangeal joints in the same $\operatorname{limb}(n=6)$, or the knee and hip $(n=2)$. Two had polyarthritis involving both knees, ankles, and wrists. Oligoarthritis always involved that part of the lower limb

Accepted for publication 24 July 1987.

Correspondence to Dr J P Huaux, Department of Rheumatology, St-Luc University Hospital, Louvain University in Brussels, Avenue Hippocrate 10, B-1200 Brussels, Belgium. in which neurological and cutaneous lesions ha developed before the appearance of the arthritis. If the two patients with polyarthritis, however, this was the presenting feature of Lyme disease. Exçept for the latter two cases, and the one abguge mentioned case of monarthritis of the knee, whe arthritis appeared simultaneously with or after ome lesions of Lyme disease such as tick or insect bites i i nine cases, erythema chronicum migrans $(n=8$, and/or neurological disease $(n=8)$; cranial neuriti $(n=1)$, lymphocytic meningitis $(n=2)$, and/or moto? and sensory radiculitis $(n=5)$.

The arthritis appeared during the first month of the disease in six cases, during the second in three during the third in two, during the fourth in one, and within the first year in another one. In one case the precise onset was unknown.

In 10 cases given complete intravenous penicilli therapy (20 MU/day for 10 days) and known course. the recovery was complete, except for one patien who developed a reflex sympathetic dystrophy syndrome of the involved foot. The mean values (SEM) of IF and ELISA were 1/162 (42) and 490 (92) respectively. All serum samples were testea. for syphilis serology (Venereal Disease Research Laboratory test, IFAT, and Treponema pallidung haemagglutination test), and all were negative. C

The 14 reported cases belong to a group of 30 patients suffering from Lyme disease studied by one of us (GB), and consisted of patients from this centre and the southern part of Belgium.

\section{Discussion}

The prevalence of definite arthritis in our group of patients with Lyme disease is rather high (47\% 
compared with the series of Muhlemann and Wright, who reported a single case among $68,{ }^{12}$ and with the French series of Baranton et al, who obtained a $34 \%$ prevalence. ${ }^{9}$ Moreover, this prevalence is higher than that in a previous group $(27 \%)$ published by one of us (GB), ${ }^{1}$ which included most of the present cases and 19 cases from the northern part of the country. In the latter group of 19 patients only a single case of arthritis was observed, but most patients suffered from isolated erythema chronicum migrans with no other features of Lyme disease. ${ }^{11}$ In contrast, our present group appears to be more severe with neurological complications in more than half of the patients. Similarly, the prevalence is higher than that in a recent report from the USA by Dattwyler et al $(20 \%)$, who reported a series of patients observed since the early 'eighties and treated with antibiotics. ${ }^{13}$ On the other hand, earlier reports from the USA established a $60 \%$ prevalence of arthritis in patients not treated with antibiotics, though only $10 \%$ of them suffered from chronic arthritis. ${ }^{1}$ The high prevalence of arthritis in our study may result from the careful search for arthritis in our cases of Lyme disease. Another explanation may be our systematic testing for $B$ burgdorferi antibodies in isolated arthritis of apparently unknown origin. The rather late diagnosis of Lyme disease in our group and hence the lack of early treatment with antibiotics is another possible explanation for this high prevalence.

Lyme arthritis in our series appeared in $78 \%$ of cases in the first three months of the disease and was seldom the presenting manifestation, except when polyarticular. The arthritis was definite, and oligoarthritis was the common mode of presentation of the articular disease $(57 \%)$, which appeared in that part of the limb where the other features of Lyme disease were present or had developed before the rheumatic manifestation. This localised pattern of the arthritis is different from the cases reported in the USA in the late 'seventies, ${ }^{1}$ where the arthritis was recurrent and of the migratory type in the initial stages of the disease, and chronic with cartilage erosion in $10 \%$ of more advanced cases. Antibiotic therapy was, however, not performed at that time. The clinical pattern of our cases resembles more closely the other cases reported in Europe. ${ }^{2.36-8}$ Some of the latter, ${ }^{25}$ however, had a more prolonged course, with polyarthritis as the more common mode of articular disease but, again, these cases were those not treated with antibiotics.

All our cases treated with penicillin IV for 10 days recovered rapidly. Hence the pattern of the arthritis suggests an infectious articular disease rather than an immunological one.
Lyme disease seems to be increasing in Europe, or at least to be more frequently recognised by the widespread use of highly sensitive serological tests detecting the presence of antibodies against $B$ burgdorferi. In early recognised cases oxytetracycline may prevent the appearance of the later complications of the disease, ${ }^{14}{ }^{15}$ but this statement has been disputed recently. ${ }^{13}$ In the other cases arthritis may develop and may, in our experience, appear as an oligoarticular disease which recovers after penicillin therapy. In future, particular attention needs to be devoted to the prompt recognition of Lyme disease and to subsequent prompt therapy.

We are grateful to Professors J Sonnet and $\mathrm{H}$ Meunier, and to Drs C Sindic, M Lambert, E Verhoeven, P Marcelis, C Boemer whose patients have been included.

\section{References}

1 Steere A C, Malawista S E. Snydman D R. et al. Lyme arthritis. An epidemic of oligoarticular arthritis in children and adults in three Connecticut communities. Arthritis Rheum 1977; 20: 7-17.

2 Illouz G. Hewitt J. A propos de l'arthrite de Lyme. Polyarthrite inflammatoire après un érythème annulaire migrant. Rev Rhum Mal Osteoartic 1981; 48: 813-5.

3 Gerster J C, Guggi S. Lyme arthritis appearing outside the United States: a case report from Switzerland. Br Med J 1981: 283: 951-2.

4 Mallecourt J. Landureau M. Wirth A M. La maladie de Lyme. Un cas clinique observé en Eure-et-Loir. La Nouvelle Presse Medicale 1982; 11: 39-41.

5 Dougados M, Kahan A, Vannier A. Amor B. Arthrite de Lyme. Deux nouveaux cas français. Rev Rhum Mal Osteoartic 1983; 50: 299-302.

6 Stiernstedt G. Granström M. Ixodes ricinus spirochete infection as the cause of postinfectious arthritis in Sweden. Scand $J$ Rheumatol 1985; 14: 336-42.

7 Stanek G. Wewalka G, Groh V. Neumann R. Kristoferitsch W. Differences between Lyme disease and European arthropodborne borrelia infections. Lancet 1985; i: 401 .

8 Allal J. Thomas Ph. Mazzonelli J. Borrelia isolated from cerebrospinal fluid in a French case of Lyme discase. Ann Rheum Dis 1986; 45: 789-90.

9 Baranton G, Edlinger C, Mazzonelli J, Dufresne Y. La borreliose dite de Lyme, maladic 'nouvelle' identifiée depuis près de 80 ans. Médecine et Maladies Infectieuses 1986; 12: 747-55.

10 Huaux J P, Nagant de Deuxchaisnes C. Lyme arthritis. Lancet 1987: i: 443 .

11 Bigaignon G. Goubau P. Desmyter J. Vandepitte J. Lyme borreliosis in Belgium. Lancet 1987: i: 557.

12 Muhlemann M F. Wright D J M. Emerging pattern of Lyme disease in the United Kingdom and Irish Republic. Lancet 1987: i: 260 -2.

13 Dattwyler R J. Volkman D J, Luft B J. Halperin J J. Lyme disease in Europe and North America. Lancet 1987: i: 681.

14 Steere A C. Malawista S E. Newman J H. Spieler P N. Bartenhagen N H. Antibiotic therapy in Lyme disease. Ann Intern Med 1980); 93: 1-8.

15 Steere A C. Hutchinson G J. Rahn D W, et al. Treatment of early manifestation of Lyme discase. Ann Intern Med 1983; 99: 22-6. 